WSRC-TR-20003-00402, Revision 0

\title{
Determination of the Effect of Uranium Levels on Sludge Batch 2 Processing
}

D. T. Herman

W. R. Wilmarth

Westinghouse Savannah River Company

Savannah River Site

Aiken, SC 29808

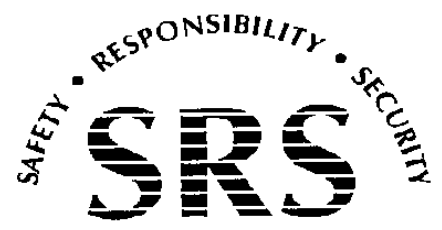

PREPARED FOR THE U.S. DEPARTMENT OF ENERGY UNDER CONTRACT NO. DE-AC09-96SR18500 
This document was prepared in conjunction with work accomplished under Contract No. DE-AC09-96SR18500 with the U. S. Department of Energy.

\section{DISCLAIMER}

This report was prepared as an account of work sponsored by an agency of the United States Government. Neither the United States Government nor any agency thereof, nor any of their employees, makes any warranty, express or implied, or assumes any legal liability or responsibility for the accuracy, completeness, or usefulness of any information, apparatus, product or process disclosed, or represents that its use would not infringe privately owned rights. Reference herein to any specific commercial product, process or service by trade name, trademark, manufacturer, or otherwise does not necessarily constitute or imply its endorsement, recommendation, or favoring by the United States Government or any agency thereof. The views and opinions of authors expressed herein do not necessarily state or reflect those of the United States Government or any agency thereof.

This report has been reproduced directly from the best available copy.

Available for sale to the public, in paper, from: U.S. Department of Commerce, National Technical Information Service, 5285 Port Royal Road, Springfield, VA 22161, phone: (800) 553-6847, fax: (703) 605-6900

email: orders@ntis.fedworld.gov

online ordering: http://www.ntis.gov/help/index.asp

Available electronically at http://www.osti.gov/bridge

Available for a processing fee to U.S. Department of Energy and its contractors, in paper, from: U.S. Department of Energy, Office of Scientific and Technical Information, P.O. Box 62, Oak Ridge, TN 37831-0062,

phone: (865)576-8401,

fax: (865)576-5728

email: $\underline{\text { reports@ adonis.osti.gov }}$ 
$\begin{array}{ll}\text { Keywords: } & \begin{array}{l}\text { Sludge Batch } 2 \\ \text { Uranium } \\ \text { SRAT }\end{array}\end{array}$

Retention: Permanent

\section{Determination of the Effect of Uranium Levels on Sludge Batch 2 Processing}

D. T. Herman

W. R. Wilmarth

Publication Date: September 2003

Westinghouse Savannah River Company

Savannah River Site

Aiken, SC 29808

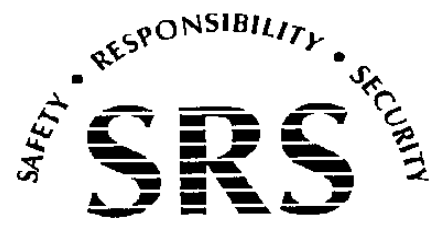

PREPARED FOR THE U.S. DEPARTMENT OF ENERGY UNDER CONTRACT NO. DE-AC09-96SR18500 



\section{TABLE OF CONTENTS}

$1.0 \quad$ Summary

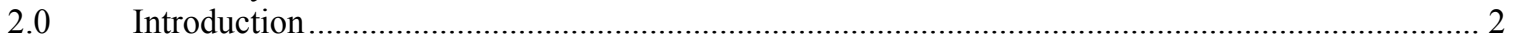

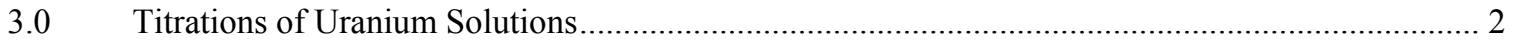

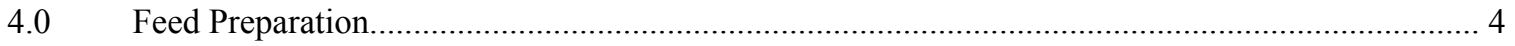

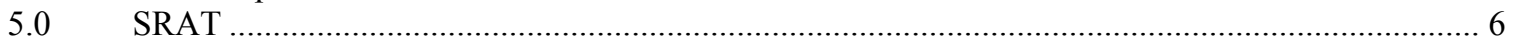

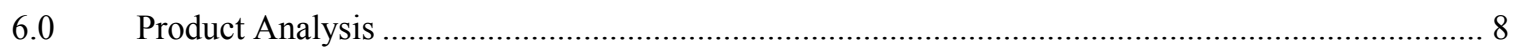

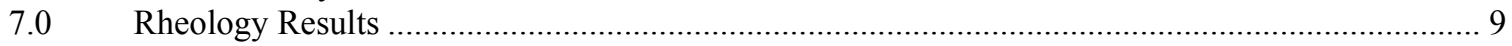

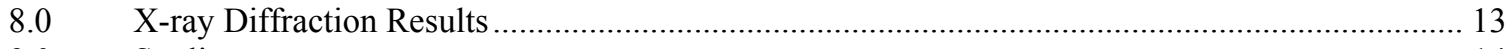

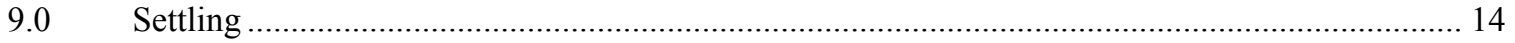

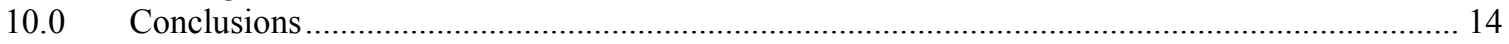

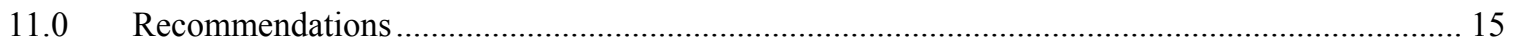

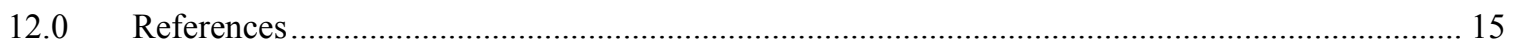

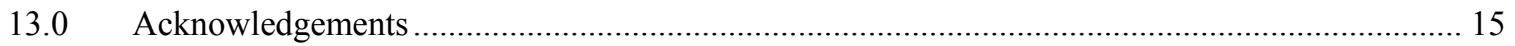

\section{List of Figures}

Figure 1. Titration of Uranyl Nitrate Solutions at Different Acid Addition Rates ...................................... 3 Figure 2. Titration of Uranium Solution with $7.5 \mathrm{Wt} \%$ Uranium in Solids at Room Temperature and $80 \mathrm{C} 3$

Figure 3. Titrations of the $15 \mathrm{Wt} \% \mathrm{U}$ Solids at Different Acid Addition Rates .......................................... 5

Figure 4. Titration Curves Of Slurries Containing 0, 7.5 and $15 \mathrm{Wt} \%$ Uranium Solids .............................. 6

Figure 5. 1 L SRAT Vessel and Associated Processing Equipment....................................................... 7

Figure 6. Acid Addition for During the SRAT Runs at All Uranium Levels .............................................. 8

Figure 7. Rheogram of All Levels of Uranium in the Initial Feed......................................................... 10

Figure 8. All Levels of Uranium, Minimum $\mathrm{pH}$

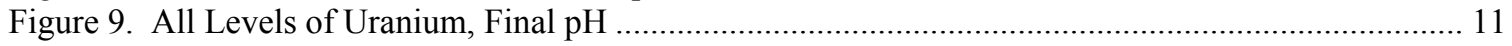

Figure 10. Rheogram of $7.5 \mathrm{wt} \%$ Uranium Solids at $50 \mathrm{C}$ and Room Temperature $(25 \mathrm{C})$.......................... 12

Figure 11. Rheogram of $15 \%$ Uranium Solids at $50 \mathrm{C}$ and Room Temperature (25 C) ........................... 12

Figure 12. X-ray Spectra for Final Product with No Uranium Added..................................................... 13

Figure 13. X-ray Spectra for Final Solution with $7.5 \mathrm{Wt} \%$ Uranium in the Solids of the Feed .................. 13

Figure 14. X-ray Spectra for Final Solution with $15 \mathrm{Wt} \%$ Uranium in the Solids of the Feed .................... 14

\section{List of Tables}

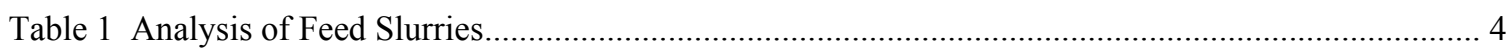

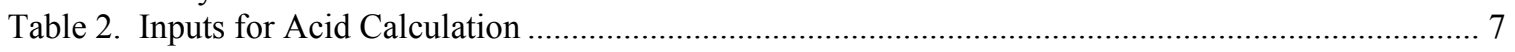

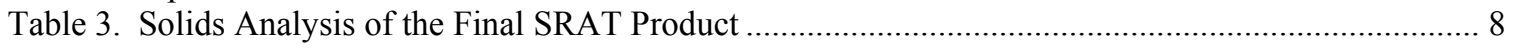

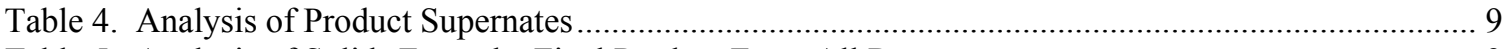

Table 5. Analysis of Solids From the Final Product From All Runs .......................................................... 9

Table 6. Percentage of Elements Dissolved Into the Supernate ……....................................................... 9 


\subsection{Summary}

Testing was done to determine what effect different levels of uranium would have on the processing of Sludge Batch 2 in the Defense Waste Processing Facility (DWPF) Chemical Processing Cell (CPC). Two levels of uranium were added to Sludge Batch 2 simulant, $7.5 \mathrm{wt} \%$ uranium solids and $15 \mathrm{wt} \%$ uranium solids and were tested along with the simulant with no uranium added. The testing started with titrations of uranyl nitrate solutions. Titrations were then performed on slurries of Sludge Batch 2 simulant, and the simulant with two levels of uranium added to determine whether uranium would increase the acid demand during processing. These same slurries were then processed through a small-scale SRAT cycle.

Titration results were shown to be affected by the acid addition rate and temperature. To maintain consistency in the SRAT testing, the acid addition rate for the titrations was selected by scaling the acid addition rate to that used by DWPF. This resulted in a base equivalence higher than that used in actual processing in DWPF and in the SRAT cycle qualification run done in the SRTC shielded cells.

Differences in physical properties were observed between the SRAT feed slurries in which the only change was the uranium concentration. These observations included the shading and thickness of the slurry. The most dramatic change in slurry properties was observed with the sludge simulant that corresponds to the uranium level found in Sludge Batch 2. The changes, however, were not conclusive enough to say whether the uranium level in Sludge Batch 2 is responsible for the processing problems. During processing with a higher concentration of uranium, slurry properties improved and in many ways slurry behavior was similar to the simulant without uranium added.

Rheology of the three SRAT sludge slurries was measured for the initial feed, after acid addition and at the end of the SRAT cycle. The slurry matching the level of uranium in the actual Sludge Batch 2, $7.5 \mathrm{wt} \%$ solids, was consistently more viscous. The slurries with no uranium and the highest concentration of uranium behaved similarly for the initial feed and after acid addition. The $7.5 \mathrm{wt} \%$ uranium solution and the solution with no uranium behaved similarly in the final product with the $7.5 \mathrm{wt} \%$ solution being more viscous. It is possible that a range of concentration for the uranium may have an adverse affect on the rheology of slurry. Concentrations above or below this range may have minimal impact on slurry properties.

$\mathrm{X}$-ray diffraction of the SRAT products showed similar compounds formed with the majority of the uranium in the form of $\mathrm{Na}\left(\left(\mathrm{UO}_{2}\right)\right)(\mathrm{OH}) *\left(\mathrm{H}_{2} \mathrm{O}\right)$ (Clarkeite) and/or $\mathrm{Na}_{2} \mathrm{U}_{2} \mathrm{O}_{7}$. The one noticeable difference was the absence of $\mathrm{Fe}_{2} \mathrm{O}_{3}$ (hematite) in the solution with the highest uranium concentration.

The SRAT products from each of the slurries were allowed to settle for several days. The slurry with the highest uranium concentration ( $15 \mathrm{wt} \%$ ) showed the greatest degree of settling. The degree of settling of the other two slurries was very similar.

A large fraction of the uranium, over seventy percent, was dissolved in the SRAT testing. This is contrary to testing with the actual Sludge Batch 2 feed where very little uranium was detected in the supernate.

Possible explanations include:

- aging of the uranium compounds in the actual sludge,

- the uranium compounds formed in the simulant were not an accurate representation of the uranium compounds in the actual sludge, and/or

- the higher levels of acid used in the simulant runs caused the uranium dissolution.

Any further work should have the uranium added to the simulant during preparation. While this will not duplicate the phases formed during aging, it will provide a better replicate of the actual sludge compounds than adding the uranium separately. 


\subsection{Introduction}

The Defense Waste Processing Facility (DWPF) began processing Sludge Batch 2 in December of 2001. Since the introduction of the first complete process batch from Sludge Batch 2, processing issues have been observed in the Sludge Receipt and Adjustment Tank (SRAT), Slurry Mix Evaporator (SME), Melter Feed Tank (MFT) and the melter. These issues coincided with the start of Batch 209, the first full batch from Sludge Batch 2. The issues involve the ability to transfer CPC products and feeding the melter, difficulty maintaining heat transfer in the SME and degradation of the operation of the melter. Although not the only difference, one of the primary differences between Sludge Batch 2 and the previous Sludge Batches is the increased content of uranium.

Small-scale tests were performed to determine the effect of different levels of uranium on sludge processing. Testing was conducted with two different sets of samples. The first set of samples were uranyl nitrate solutions. The purpose of these solutions was to isolate the uranium from other elements that could affect processing of the sludge. The second set of samples consisted of Sludge Batch 2 simulant with uranium added at two levels to create slurries with $0,7.5$ and $15 \mathrm{wt} \%$ uranium. These slurries were compared to each other after undergoing a small-scale SRAT process. The rheology of samples from each run was measured to determine the effect of increasing uranium levels.

\subsection{Titrations of Uranium Solutions}

Titrations were performed on the three different solutions with varying uranium levels. These solutions were prepared by dissolving uranyl-nitrate crystals in dilute nitric acid and then raising the $\mathrm{pH}$ using 50 $\mathrm{wt} \%$ sodium hydroxide. This was done to simulate the plant process. These solutions were then washed with inhibited water to bring the solutions to similar free hydroxide levels.

Two of the three solutions contained different levels of uranium while the third contained no uranium. One of the solutions with uranium added contained approximately $7.5 \mathrm{wt} \%$ uranium in the dried solids. This level approximates the uranium content of Sludge Batch 2. The second uranium level was simply the doubling of the uranium level in the solids to determine the effects of a higher concentration of uranium on the processing of the sludge.

For each solution containing uranium, at least two titrations were performed at room temperature using a baseline acid addition rate of $7.5 \mu \mathrm{L} / \mathrm{min}$, which was scaled to the addition rate used in DWPF. The second acid addition rate used doubled the scaled DWPF addition rate. An additional titration was done at $80 \mathrm{C}$. The solution with no uranium was titrated at the two temperatures; the acid addition rate was not changed.

During experimentation it was noted that the rate of acid addition greatly affected acid demand. Figure 1 shows the titrations at different acid addition rates for all uranium concentrations. In general, the uranium solutions required more acid for the faster acid addition rate. The additional acid required was primarily due to the formation of intermediate uranium compounds as seen in earlier studies during the evaporator program. ${ }^{3}$ The solution with no uranium exhibited the opposite behavior, requiring slightly more acid at the lower addition rate. For the accelerated acid addition ratet pHs less than 6 the level of uranium dictated the acid demand more than the acid addition rate. At this point the uranium is dominating the chemistry of the solution.

Figure 2 compares the titrations for the $7.5 \mathrm{wt} \%$ uranium solids performed at room temperature and $80 \mathrm{C}$. At the elevated temperature the acid demand at different acid addition rates showed the opposite trend as the titrations done at room temperatures. At the higher temperature, less acid was required with the higher addition rate. This trend was repeated in the $15 \mathrm{wt} \%$ uranium solids titrations. The differences in the behavior were anticipated based on reactions observed in the SRAT due to increased reaction rates at elevated temperatures. As the reactions are accelerated at the higher temperature, less acid is required and the acid is consumed more efficiently. 
As expected, acid demand increased for the solutions with uranium. Increasing the uranium concentration tended to further increased the acid demand but not by an equivalent stoichiometric amount.

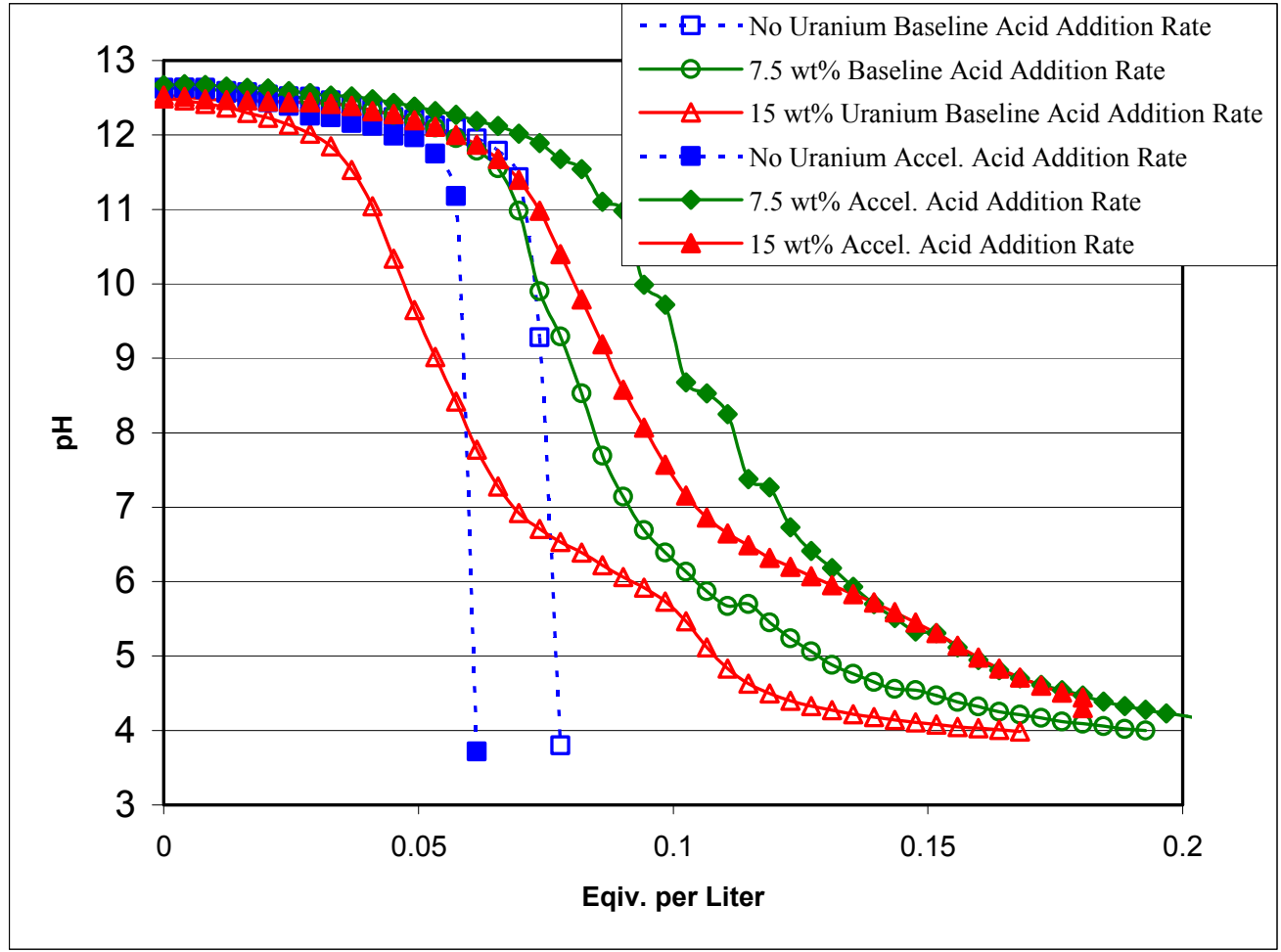

Figure 1. Titration of Uranyl Nitrate Solutions at Different Acid Addition Rates

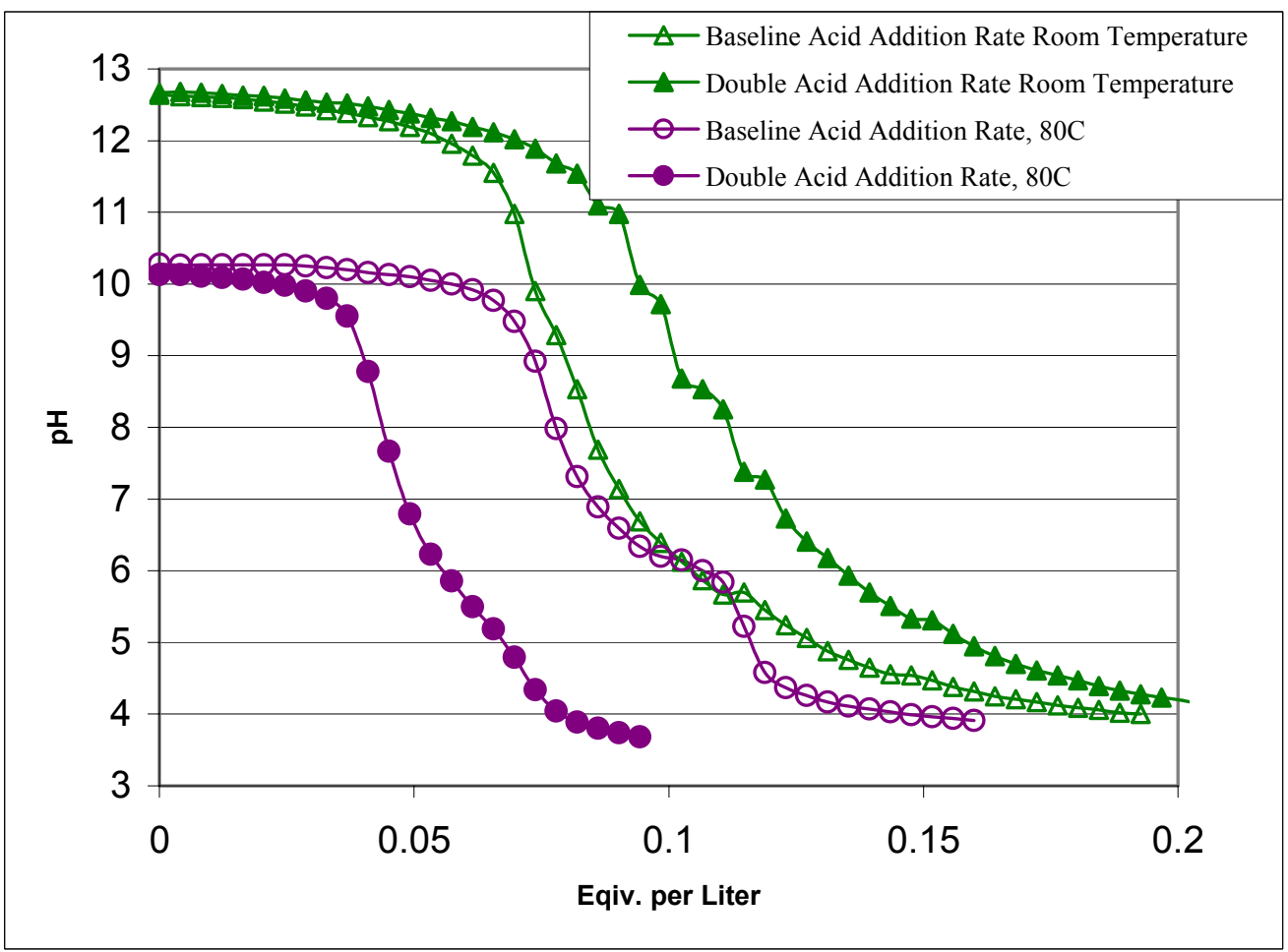

Figure 2. Titration of Uranium Solution with $7.5 \mathrm{Wt} \%$ Uranium in Solids at Room Temperature and $80 \mathrm{C}$ 


\subsection{Feed Preparation}

Sludge Batch 2 simulant was obtained from drum \# RM-03-131. Approximately two liters of simulant were obtained and split into three samples. The nitrite level for the simulant was raised to match actual Sludge Batch 2 concentrations more closely. No mercury or noble metals were added to simulant to allow for easier processing and disposal after the completion of the testing.

The first slurry was used as it was obtained from the drum. Uranium was added to the second and the third slurries as uranyl-nitrate. Uranyl nitrate crystals were dissolved in $0.2 \mathrm{M}$ nitric acid and then diluted with deionized water. The uranium solution was then added to the sludge simulant. The addition of the uranium lowered the $\mathrm{pH}$ of the slurry from an initial value of 12.7 to 8.44 for the $7.5 \mathrm{wt} \%$ solution and to 6.09 for the $15 \mathrm{wt} \%$ solution. The $\mathrm{pH}$ was raised by adding $5.5 \mathrm{~mL}$ and $15.3 \mathrm{~mL}$ of $50 \mathrm{wt} \% \mathrm{NaOH}$ respectively. This brought the resulting $\mathrm{pH}$ values to 12.45 and 12.33 for the two slurries.

The feed solutions were then analyzed to determine elemental composition. Table 1 shows the analysis of the slurries.

Table 1 Analysis of Feed Slurries

\begin{tabular}{|c|c|c|c|}
\hline Analyte & $\begin{array}{c}\mathbf{0} \mathbf{w t} \% \mathbf{U} \text { Feed } \\
(\boldsymbol{\mu g} / \mathbf{g})\end{array}$ & $\begin{array}{c}\mathbf{7 . 5} \mathbf{w t \%} \mathbf{U} \text { Feed } \\
(\boldsymbol{\mu g} / \mathbf{g})\end{array}$ & $\begin{array}{c}\mathbf{1 5} \mathbf{w t \%} \text { U Feed } \\
(\boldsymbol{\mu} \mathbf{g} / \mathbf{g})\end{array}$ \\
\hline $\mathrm{Al} \mu \mathrm{g} / \mathrm{g}$ & 13100 & 12000 & 11300 \\
\hline $\mathrm{Ca} \mu \mathrm{g} / \mathrm{g}$ & 4540 & 4150 & 3960 \\
\hline $\mathrm{Fe} \mu \mathrm{g} / \mathrm{g}$ & 54700 & 49700 & 47600 \\
\hline $\mathrm{Mg} \mu \mathrm{g} / \mathrm{g}$ & 228 & 205 & 198 \\
\hline $\mathrm{Mn} \mu \mathrm{g} / \mathrm{g}$ & 7270 & 6710 & 5830 \\
\hline $\mathrm{Si} \mu \mathrm{g} / \mathrm{g}$ & 1890 & 1700 & 1650 \\
\hline $\mathrm{U} \mu \mathrm{g} / \mathrm{g}$ & 1660 & 15200 & 29700 \\
\hline $\mathrm{Zn} \mu \mathrm{g} / \mathrm{g}$ & 593 & 537 & 509 \\
\hline $\mathrm{Zr} \mu \mathrm{g} / \mathrm{g}$ & 962 & 937 & 447 \\
\hline
\end{tabular}

Each solution was titrated using $10.25 \mathrm{M}$ nitric acid. As with the titration of the uranium solutions, acid demand differed with a change in acid addition rate from $7.5 \mu \mathrm{L} / \mathrm{min}$ to $15 \mu \mathrm{L} / \mathrm{min}$. The most dramatic difference is shown in Figure 3, the titration of the highest uranium concentration. 


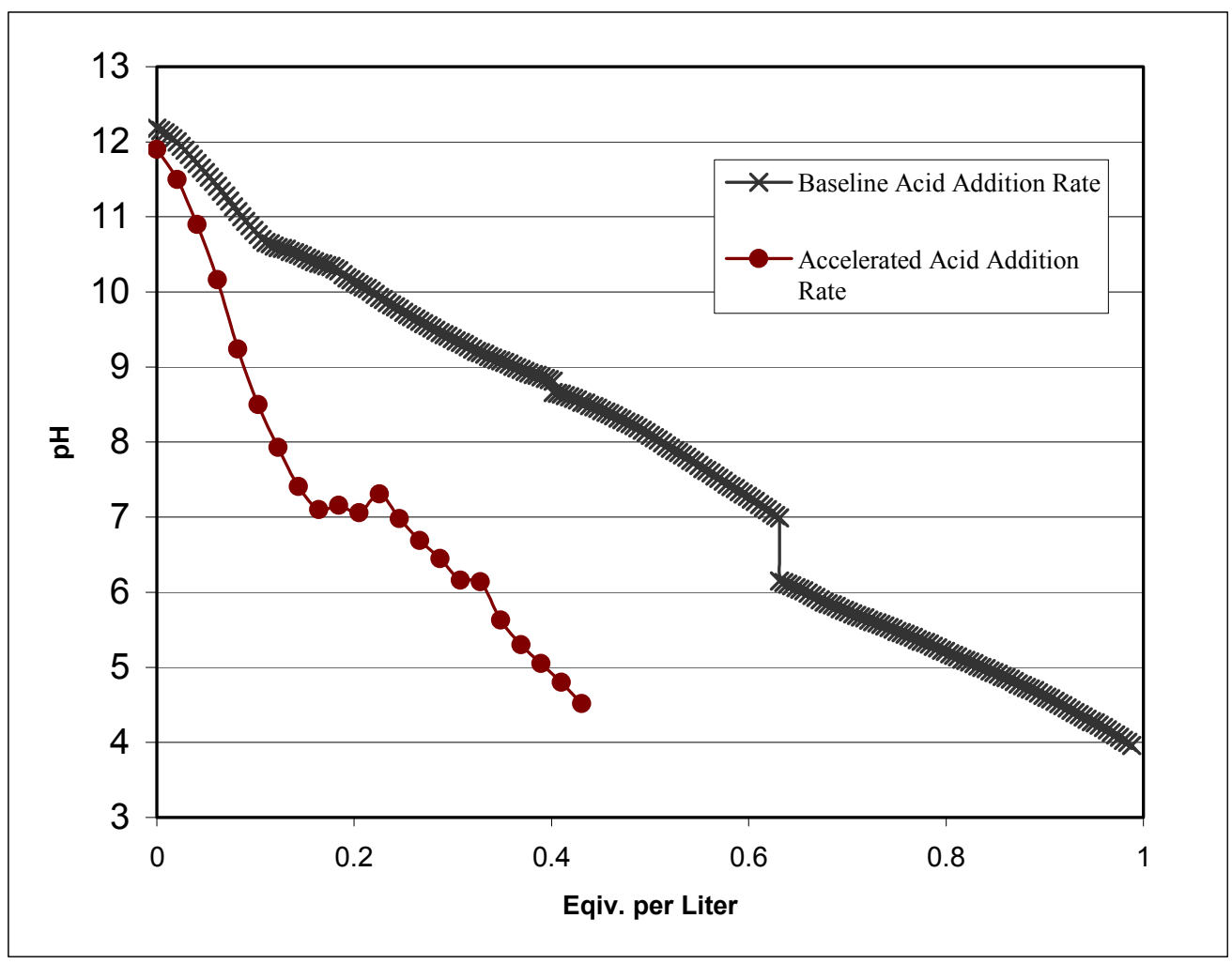

Figure 3. Titrations of the 15 Wt \% U Solids at Different Acid Addition Rates

As the titration at the faster addition rate was being performed, it was determined that $\mathrm{pH}$ was dropping significantly therefore the titration was stopped at a $\mathrm{pH}$ of approximately 7.1 and allowed to equilibrate overnight. This was done to determine if the $\mathrm{pH}$ would rise as the reactions were allowed to come to completion. The following morning, the titration was resumed. The $\mathrm{pH}$ rose to 7.3 in the 20 hours that the slurry was allowed to sit with the mixer off. The total titration time was 2 hours, with significantly less acid required to adjust $\mathrm{pH}$. It is believed that at the slower addition rate the acid was being consumed in other reactions such as the destruction of nitrites and not used entirely towards the base equivalents. The equilibration time of the electrode or reaction time for the base equivalence is longer than the acid association time with cations. The sudden drop in $\mathrm{pH}$ for the baseline acid addition rate titration at $\mathrm{pH} 7$ coincided with a one hour pause in acid addition due to technician availability. The drop in $\mathrm{pH}$ is attributed to additional mixing/reaction time for the sample. It was noted during testing that the slurry was thickening and some of the acid appeared to be resting on top of the slurry. This stratification has been observed in previous studies involving the $\mathrm{pH}$ adjustments. ${ }^{3}$ In that study the uranium slurry exhibited an increase in viscosity in the region of caustic addition. This increase in viscosity reduced mixing and led to the stratification of the slurry. The short break allowed the acid to mix into the slurry and consequently lower the $\mathrm{pH}$.

Titrations were attempted at elevated temperatures using the slurries but could not be completed due to the evaporation of the slurry. A curve for the simulant without uranium was obtained at $60 \mathrm{C}$ and agreed with the titrations of the simulant at room temperature.

Since the titrations are used as input for the acid calculations for the SRAT runs, it was decided to use the data obtained from the runs using the baseline acid addition rate and room temperature. This would allow input for all runs to be based on the same conditions.

Figure 4 shows examples of the titration curves at the different uranium concentrations. 


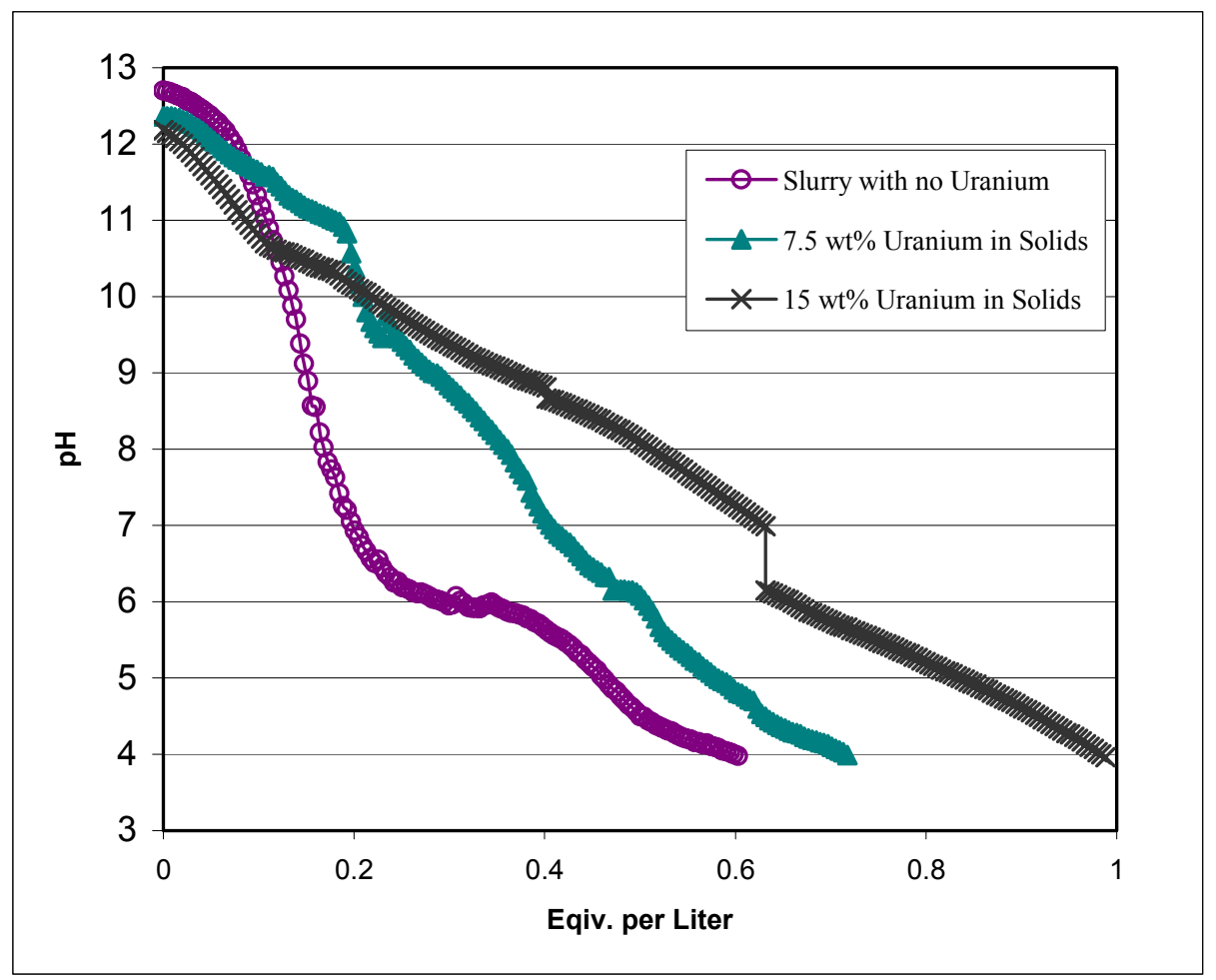

Figure 4. Titration Curves Of Slurries Containing 0, 7.5 and 15 Wt\% Uranium Solids

As illustrated back in Figure 1, more acid was required for the $7.5 \mathrm{wt} \%$ uranium solution than the $15 \mathrm{wt} \%$ solution. This indicates that at the $7.5 \mathrm{wt} \%$ concentration, interim compounds are being formed in the uranium solution that consume acid without sludge components present. As the acid addition rate was increased, the reactions were driven to completion at a faster rate and saturation was probably reached. This explains why below $\mathrm{pH}$ of 6 the acid demand for the two uranium levels in solution tracked the same.

Figure 4 shows that for the sludge simulant containing uranium, more acid was required as the uranium levels were increased. With the sludge slurries, reactions were occurring between the uranium and sludge components resulting in different compounds being formed. The formed compounds would be expected to differ with the different levels of uranium.

\subsection{SRAT}

The experimental setup included a one-liter SRAT vessel and the associated processing equipment as shown in Figure 5. Mixing was accomplished using a lightning mixer. The vessel was continuously purged at approximately $100 \mathrm{sccm} / \mathrm{min}$ using plant air. Temperature and $\mathrm{pH}$ were continuously monitored throughout the runs. A condenser was also used with chilled water supplied by an ice water circulated using a small pump. 


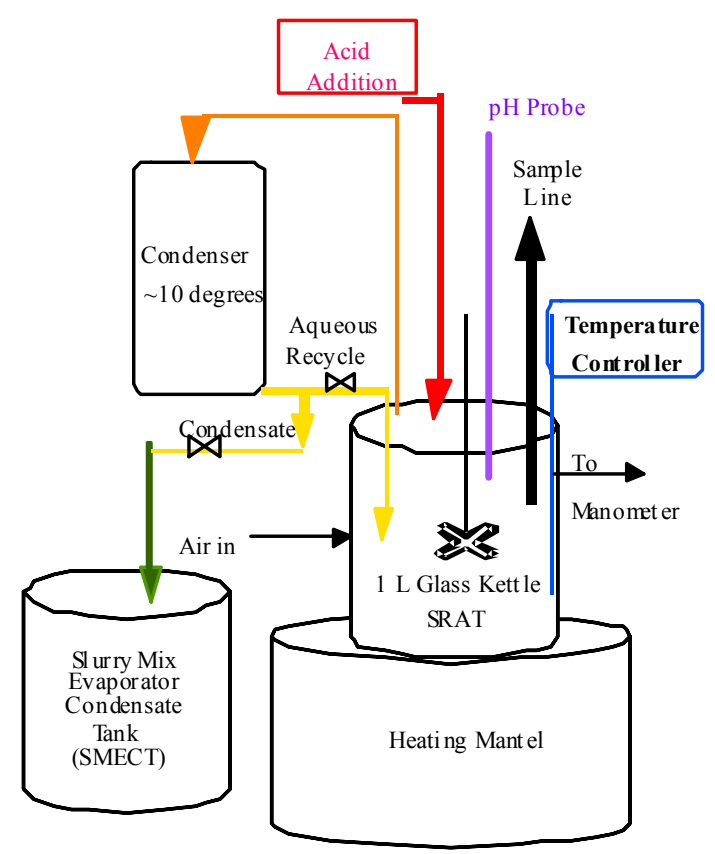

Figure 5. 1 L SRAT Vessel and Associated Processing Equipment

The percent acid in excess stoichiometric ratio for the SRAT runs was $170 \%$ and the target redox ratio $\left(\mathrm{Fe}^{++} / \mathrm{Fe}^{+++}\right)$was 0.2 . The inputs to the acid calculation spreadsheet are shown in Table 2. The spreadsheet used is the Chemical Process Cell calculation sheet version dated 6/3/2003.

Table 2. Inputs for Acid Calculation

\begin{tabular}{|c|c|c|c|}
\hline & $\mathbf{0 ~ w t \% ~ U}$ solids & $\mathbf{7 . 5} \mathbf{~ w t} \%$ U solids & $\mathbf{1 5} \mathbf{~ w t \% ~ U}$ solids \\
\hline Nitrite $(\mu \mathrm{g} / \mathrm{g})$ & 6180 & 4641 & 4604 \\
\hline Nitrate $(\mu \mathrm{g} / \mathrm{g})$ & 4180 & 9144 & 18393 \\
\hline Density $(\mathrm{g} / \mathrm{mL})$ & 1.15 & 1.11 & 1.12 \\
\hline Wt \% solids $($ total) & 19.17 & 20.35 & 22.8 \\
\hline Wt\% insoluble solids & 17.18 & 17.14 & 460.2 \\
\hline Slurry Mass $(\mathrm{g})$ & 460.2 & 460.2 & 0.63 \\
\hline Base Equivalence $(\mathrm{eq} / \mathrm{L})$ & 0.22 & 0.43 & 4.76 \\
\hline $\begin{array}{c}\text { Total Nitric Acid Added } \\
(\mathrm{mL})\end{array}$ & 6.51 & 6.80 & 28.96 \\
\hline $\begin{array}{c}\text { Total Formic Acid } \\
\text { Added }(\mathrm{mL})\end{array}$ & 17.56 & 22.69 & 2.94 \\
\hline $\begin{array}{c}\text { Total Anti-Foam IIT747 } \\
\text { Added }(\mathrm{g})\end{array}$ & 2.94 & 2.95 & \\
\hline
\end{tabular}

Figure 6 shows the acid addition for each of the three SRAT runs. The increase in $\mathrm{pH}$ at the start of the 7.5 wt $\%$ run may indicate the formation of $\mathrm{U}(\mathrm{OH})\left(\mathrm{NO}_{3}\right)$ compounds. After a $\mathrm{pH}$ of 5 was reached, all runs tracked similarly. All runs ended at low $\mathrm{pH}$ with no appreciable change in the $\mathrm{pH}$ during boiling. Constant $\mathrm{pH}$ indicates the no additional reactions were occurring. 


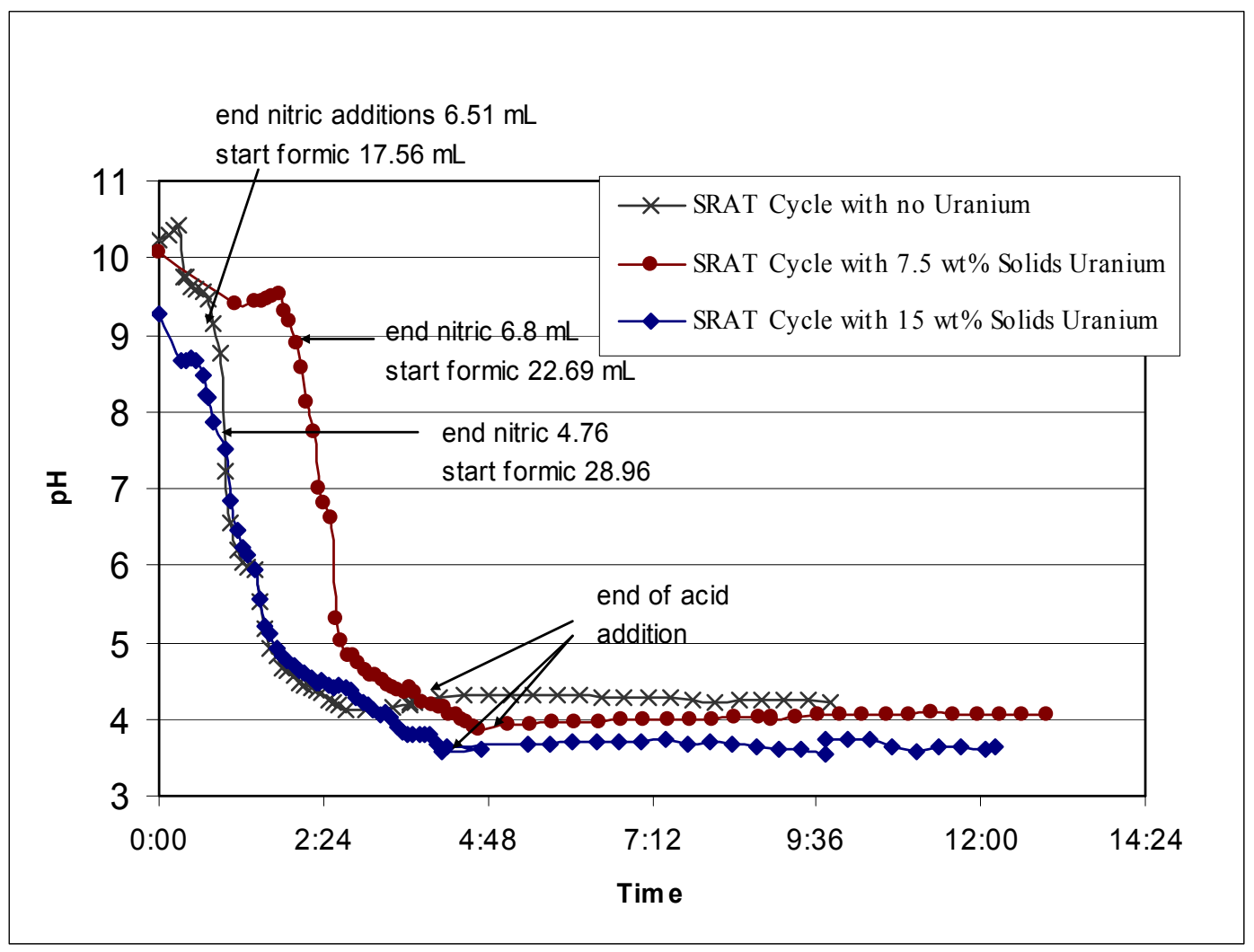

Figure 6. Acid Addition for During the SRAT Runs at All Uranium Levels

The $\mathrm{pH}$ of the final slurries after several days at room temperature was measured. They were 4.06 for the 0 $\mathrm{wt} \%$ run, 3.56 for the $7.5 \mathrm{wt} \%$ run and 3.36 for the $15 \mathrm{wt} \%$ run. The $7.5 \mathrm{wt} \%$ slurry showed the most dramatic change.

\subsection{Product Analysis}

The final product from each run was analyzed to determine solids content and elemental concentration of the supernate and solids. The solids analysis is shown in Table 3. Total and dissolved solids were measured and then insoluble and soluble solids were calculated. The run with the highest uranium had the highest total solids since no attempt was made to adjust the level of solids in the slurry for the additional uranium added. It also had the highest soluble solids likely due to the extra acid added. Table 4 shows the analysis of the supernate from each run.

Table 3. Solids Analysis of the Final SRAT Product

\begin{tabular}{|c|c|c|c|}
\hline $\begin{array}{c}\text { Sample } \\
\text { wt \% U }\end{array}$ & $\begin{array}{c}\text { Total Solids } \\
\mathbf{w t} \%\end{array}$ & $\begin{array}{c}\text { Insoluble Solids } \\
\mathbf{w t} \%\end{array}$ & $\begin{array}{c}\text { Soluble Solids } \\
\mathbf{w t \%}\end{array}$ \\
\hline 0 & 20.7 & 14.9 & 6.8 \\
\hline 7.5 & 23.2 & 13.1 & 10.0 \\
\hline 15 & 26.0 & 12.3 & 13.7 \\
\hline
\end{tabular}


Table 4. Analysis of Product Supernates

\begin{tabular}{|c|c|c|c|c|c|c|c|c|c|c|c|}
\hline $\begin{array}{c}\text { Sample } \\
\mathbf{w t} \%\end{array}$ & $\begin{array}{c}\mathbf{A l} \\
\mathbf{m g} / \mathbf{l}\end{array}$ & $\begin{array}{c}\mathbf{C a} \\
\mathbf{m g} / \mathbf{l}\end{array}$ & $\begin{array}{c}\mathbf{F e} \\
\mathbf{m g} / \mathbf{l}\end{array}$ & $\begin{array}{c}\mathbf{K} \\
\mathbf{m g} / \mathbf{l}\end{array}$ & $\begin{array}{c}\mathbf{M g} \\
\mathbf{m g} / \mathbf{l}\end{array}$ & $\begin{array}{c}\mathbf{M n} \\
\mathbf{m g} / \mathbf{l}\end{array}$ & $\begin{array}{c}\mathbf{N a} \\
\mathbf{m g} / \mathbf{l}\end{array}$ & $\begin{array}{c}\mathbf{S i} \\
\mathbf{m g} / \mathbf{l}\end{array}$ & $\begin{array}{c}\mathbf{U} \\
\mathbf{m g} / \mathbf{l}\end{array}$ & $\begin{array}{c}\mathbf{Z n} \\
\mathbf{m g} / \mathbf{l}\end{array}$ & $\begin{array}{c}\mathbf{Z r} \\
\mathbf{m g} / \mathbf{l}\end{array}$ \\
\hline 0 & 211 & 5780 & 15.7 & 366 & 241 & 8590 & 12000 & 102 & 21.5 & 301 & 0.022 \\
\hline 7.5 & 387 & 5620 & 116 & 391 & 222 & 8580 & 15800 & 76.3 & 20200 & 331 & $<0.010$ \\
\hline 15 & 509 & 5220 & 271 & 400 & 211 & 7860 & 21700 & 82.2 & 40700 & 341 & $<0.010$ \\
\hline
\end{tabular}

Significant quantities of the uranium were dissolved in the two runs with uranium added. A small amount of uranium was detected in the 0 slurry but this was probably due to contamination. These findings differed from previous testing of Sludge Batch 2 in which only trace quantities of uranium were dissolved (WSRC-TR-2002-00076). This dissolution could have been due to:

- aging of the uranium compounds in the actual sludge,

- the uranium compounds formed in the simulant were not an accurate representation of the uranium compounds in the actual sludge, and/or

- the higher levels of acid used in the simulant runs caused the uranium dissolution.

Table 5 shows the analysis of the product solids from each run. Typically the concentrations of the sludge elements decreased with an increase in added uranium. The increase in sodium was a result of the additional sodium hydroxide added to both uranium solutions during feed preparation.

Table 5. Analysis of Solids From the Final Product From All Runs

\begin{tabular}{|c|c|c|c|c|c|c|c|c|c|c|c|}
\hline Sample & $\begin{array}{c}\mathbf{A l} \\
\mathbf{w t} \%\end{array}$ & $\begin{array}{c}\mathbf{C a} \\
\mathbf{w t} \%\end{array}$ & $\begin{array}{c}\mathbf{F e} \\
\mathbf{w t} \%\end{array}$ & $\begin{array}{c}\mathbf{K} \\
\mathbf{w t} \%\end{array}$ & $\begin{array}{c}\mathbf{M g} \\
\mathbf{w t} \%\end{array}$ & $\begin{array}{c}\mathbf{M n} \\
\mathbf{w t} \%\end{array}$ & $\begin{array}{c}\mathbf{N a} \\
\mathbf{w t} \%\end{array}$ & $\begin{array}{c}\mathbf{S i} \\
\mathbf{w t} \%\end{array}$ & $\begin{array}{c}\mathbf{U} \\
\mathbf{w t} \%\end{array}$ & $\begin{array}{c}\mathbf{Z n} \\
\mathbf{w t} \%\end{array}$ & $\begin{array}{c}\mathbf{Z r} \\
\mathbf{w t} \%\end{array}$ \\
\hline 0 & 9.89 & 3.47 & 35.8 & 0.094 & 0.149 & 5.12 & 6.47 & 1.16 & $<0.100$ & 0.368 & 0.573 \\
\hline 7.5 & 8.24 & 2.97 & 29.8 & 0.091 & 0.121 & 4.26 & 7.37 & 0.986 & 9.57 & 0.314 & 0.484 \\
\hline 15 & 7.22 & 2.35 & 26.5 & 0.064 & 0.096 & 3.47 & 8.63 & 0.864 & 17.1 & 0.263 & 0.423 \\
\hline
\end{tabular}

Table 6 shows the relative percentage of the total elements that were soluble at the end of SRAT processing. This was calculated based on data in Table 4 and Table 5, along with the measured densities.

Table 6. Percentage of Elements Dissolved Into the Supernate

\begin{tabular}{|c|c|c|c|c|c|c|c|c|c|c|c|}
\hline Sample & Al & $\mathbf{C a}$ & $\mathbf{F e}$ & $\mathbf{K}$ & $\mathbf{M g}$ & $\mathbf{M n}$ & $\mathbf{N a}$ & $\mathbf{S i}$ & $\mathbf{U}$ & $\mathbf{Z n}$ & $\mathbf{Z r}$ \\
\hline 0 & 0.84 & 65.5 & 0.02 & 100 & 63.5 & 65.9 & 72.8 & 3.47 & 0.00 & 32.2 & 0.00 \\
\hline 7.5 & 1.61 & 65.1 & 0.13 & 100 & 63.3 & 69.2 & 73.6 & 2.66 & 72.5 & 36.3 & 0.00 \\
\hline 15 & 2.12 & 66.6 & 0.31 & 100 & 65.9 & 67.9 & 75.4 & 2.85 & 71.6 & 39.0 & 0.00 \\
\hline
\end{tabular}

The data indicates that over 70 percent of the uranium dissolved. As discussed previously and based on the SRAT processing with actual sludge in the shielded cells ${ }^{4}$, minimal uranium dissolution was expected. Changes in the dissolved metal ion composition varied little between the three runs. Small changes were noted in the concentration of aluminum, iron, manganese, silica and zinc.

\subsection{Rheology Results}

Nine slurry samples were initially submitted for rheological analysis. Samples at each uranium level were taken for the initial feed, the end of acid addition (or at minimum $\mathrm{pH}$ ), and final product slurries. In all three cases the $7.5 \% \mathrm{U}$ was most viscous. The initial feed sample of the $7.5 \% \mathrm{U}$ was the only sample that appeared viscous coming out of the bottle. All of the other samples mixed readily, and poured easily, although there were some visual differences. Air entrainment was not obvious when pouring. 
The initial feed with the $7.5 \mathrm{wt} \%$ uranium level showed a definite difference in slurry rheology. As noted above, the slurry appeared thicker and was harder to pour. The rheogram shown in Figure 7 confirms the visual observations. The rheology of the $15 \mathrm{wt} \%$ uranium feed was shown to be similar to the simulant with no uranium added. It is possible that a specific range of uranium concentration exists that may adversely affect the physical properties of a slurry. Potentially, once above that concentration, the slurry rheological properties may improve. Additional testing would be required with different uranium levels to determine what concentrations begin to adversely affect slurry properties and at what concentration they begin to improve again.

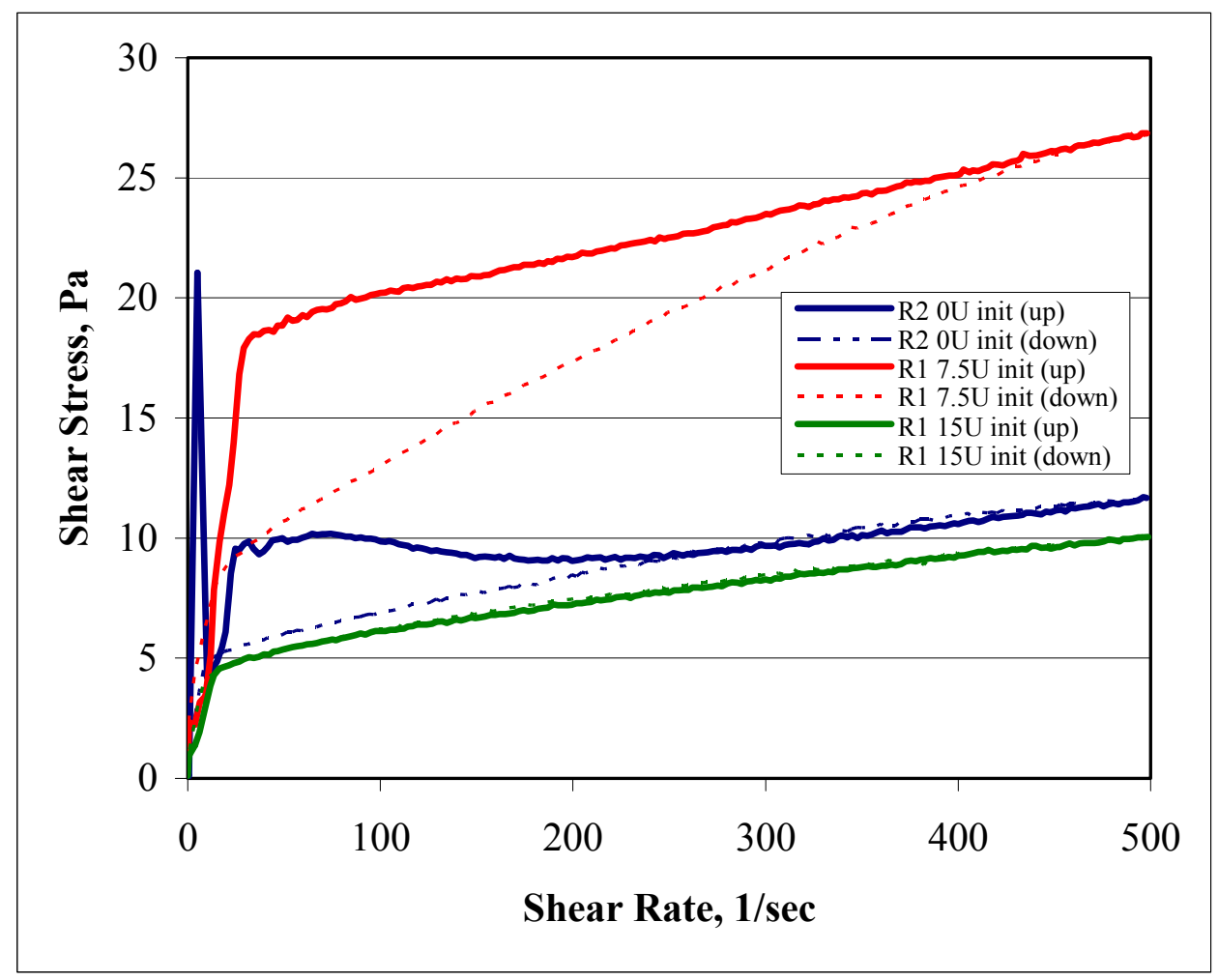

Figure 7. Rheogram of All Levels of Uranium in the Initial Feed

Figure 8 illustrates that after the acid addition is completed and the slurry is at the minimum pH, the 7.5 $\mathrm{wt} \%$ slurry again is the most viscous. At this point, the slurry with no uranium and the slurry with $15 \mathrm{wt} \%$ uranium in the solids are essentially identical in the rheology measurements. The differences in the viscosity of the slurries are most probably due to the formation of sodium-alumino-silicate-uranium compounds in the 0 and $15 \mathrm{wt} \%$ slurries. The viscosity of the $7.5 \mathrm{wt} \%$ slurries is probably due to interim uranium iron compounds. 


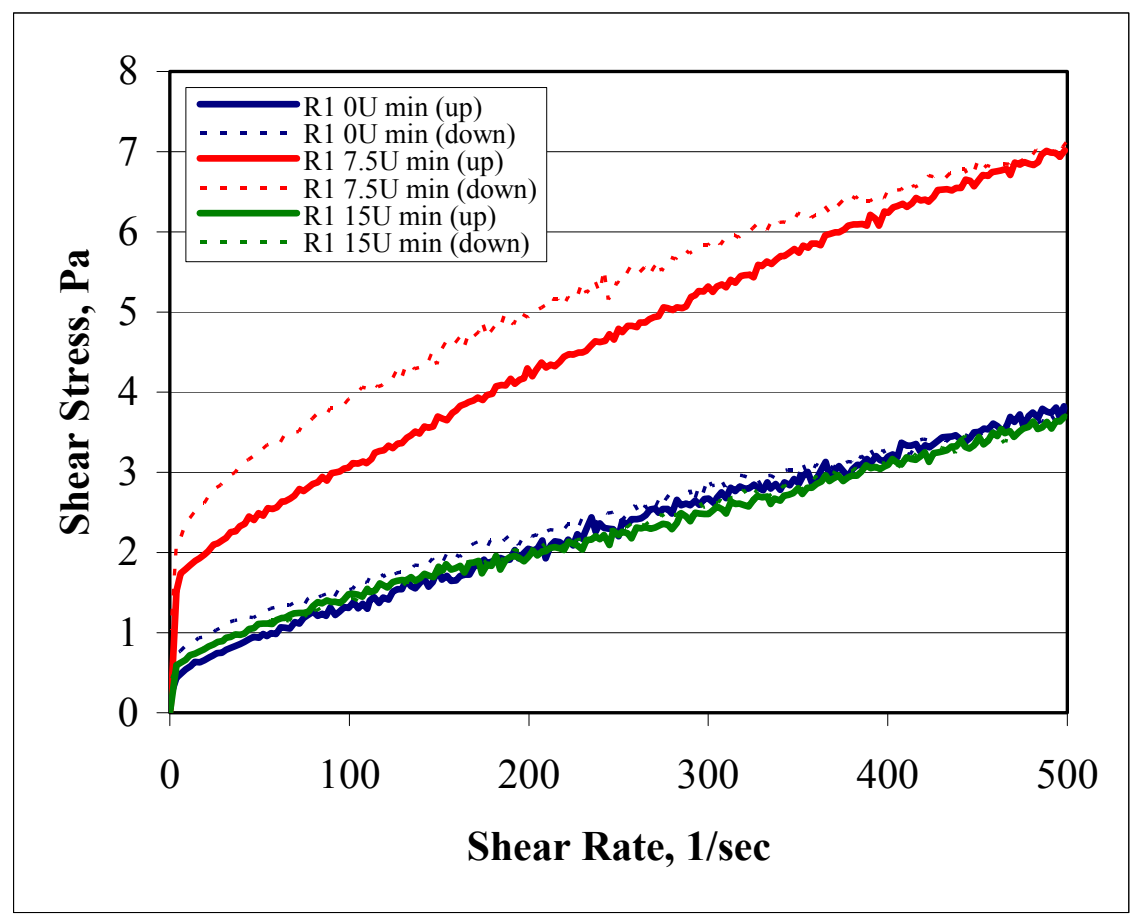

Figure 8. All Levels of Uranium, Minimum pH

Figure 9 shows the rheograms for the final products from all three runs. These should represent the slurries that DWPF would be transferring to the SME. The product from the $7.5 \mathrm{wt} \%$ run again indicates a relatively thicker slurry, with the slurry from the $0 \mathrm{wt} \%$ run showing similar results. The product from the $15 \mathrm{wt} \%$ run shows less shear and is the least viscous slurry. However, it is not clear whether the low viscosity is due to the uranium level or the acid added during processing.

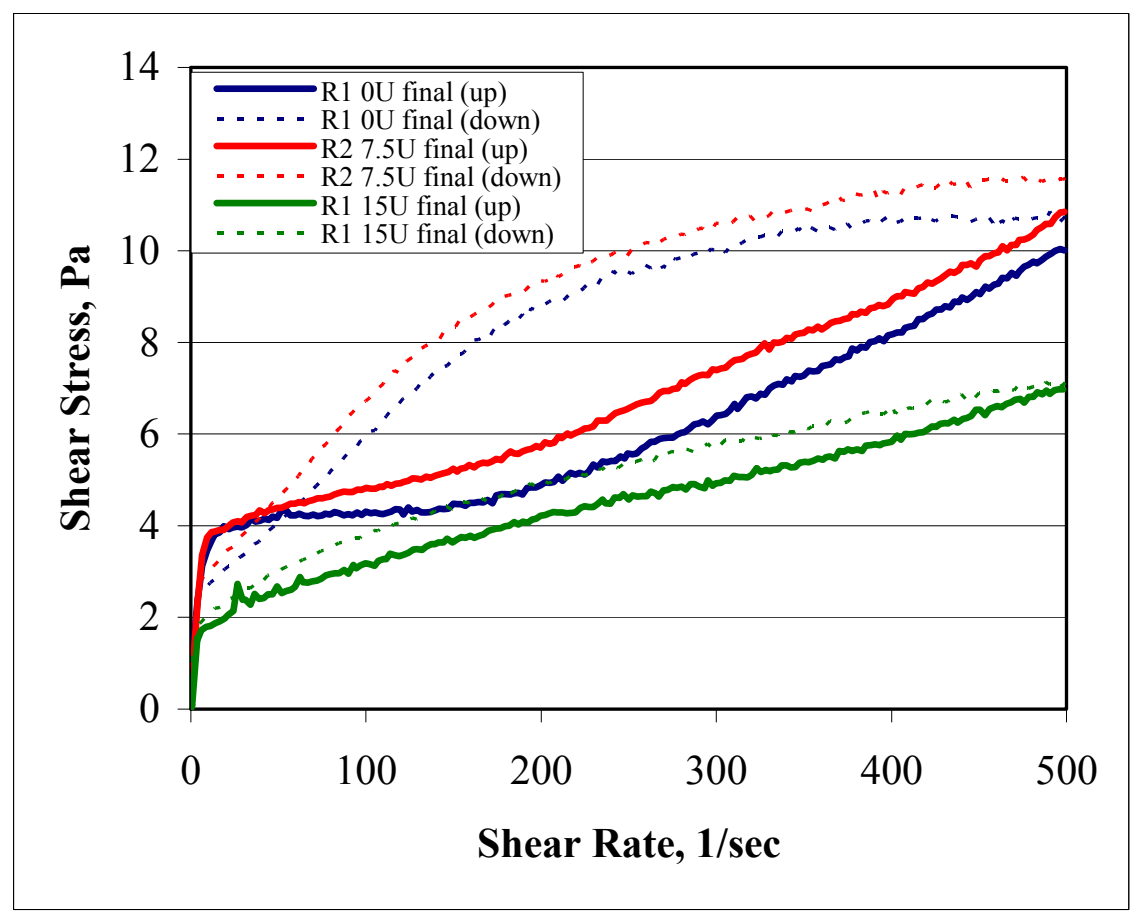

Figure 9. All Levels of Uranium, Final pH 
Analysis was then done at $50 \mathrm{C}$ for the two cases with uranium to determine if temperature affected the viscosity of the slurry. The resulting rheograms are shown as Figure 10 and Figure 11.

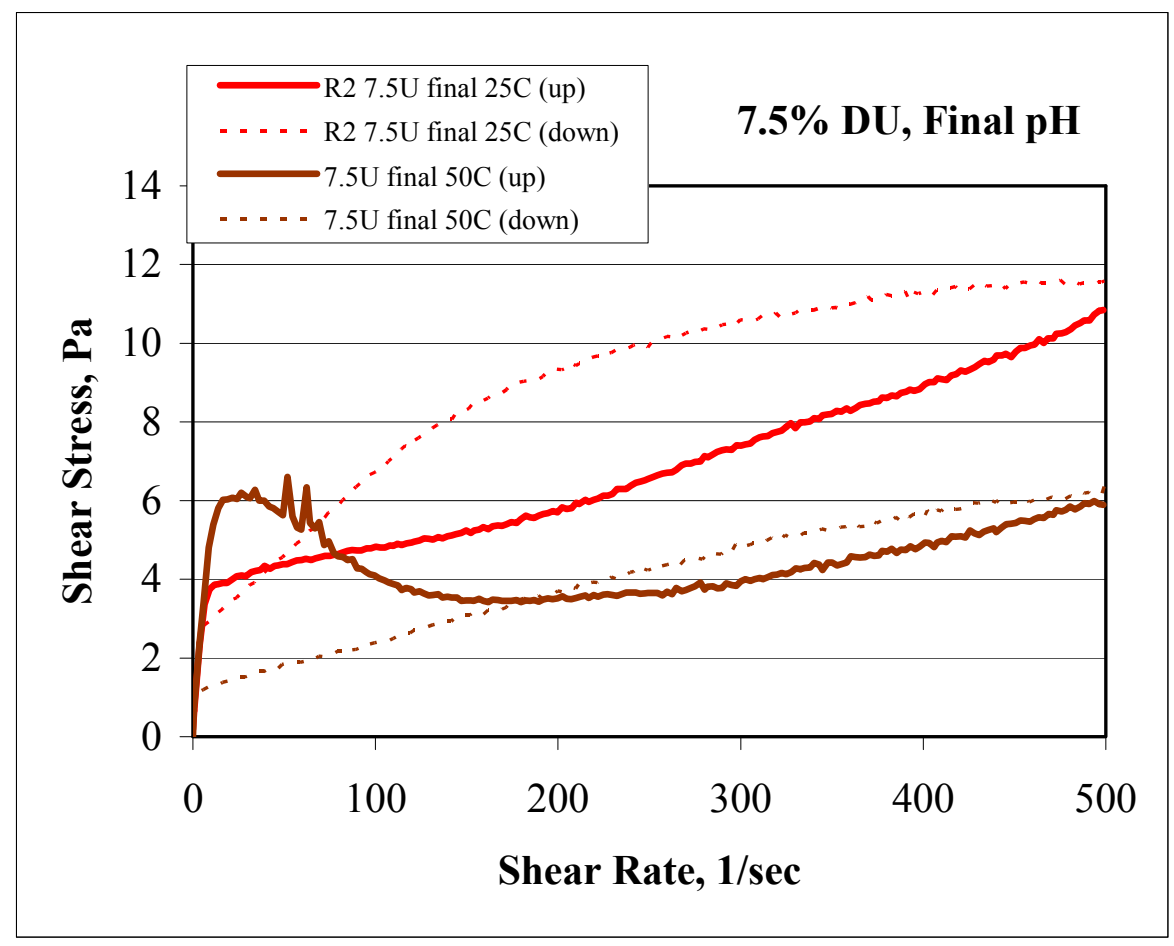

Figure 10. Rheogram of $7.5 \mathrm{wt} \%$ Uranium Solids at $50 \mathrm{C}$ and Room Temperature (25 C)

The rheogram for the $15 \mathrm{wt} \%$ case showed very little change with temperature in the viscosity of the slurry.

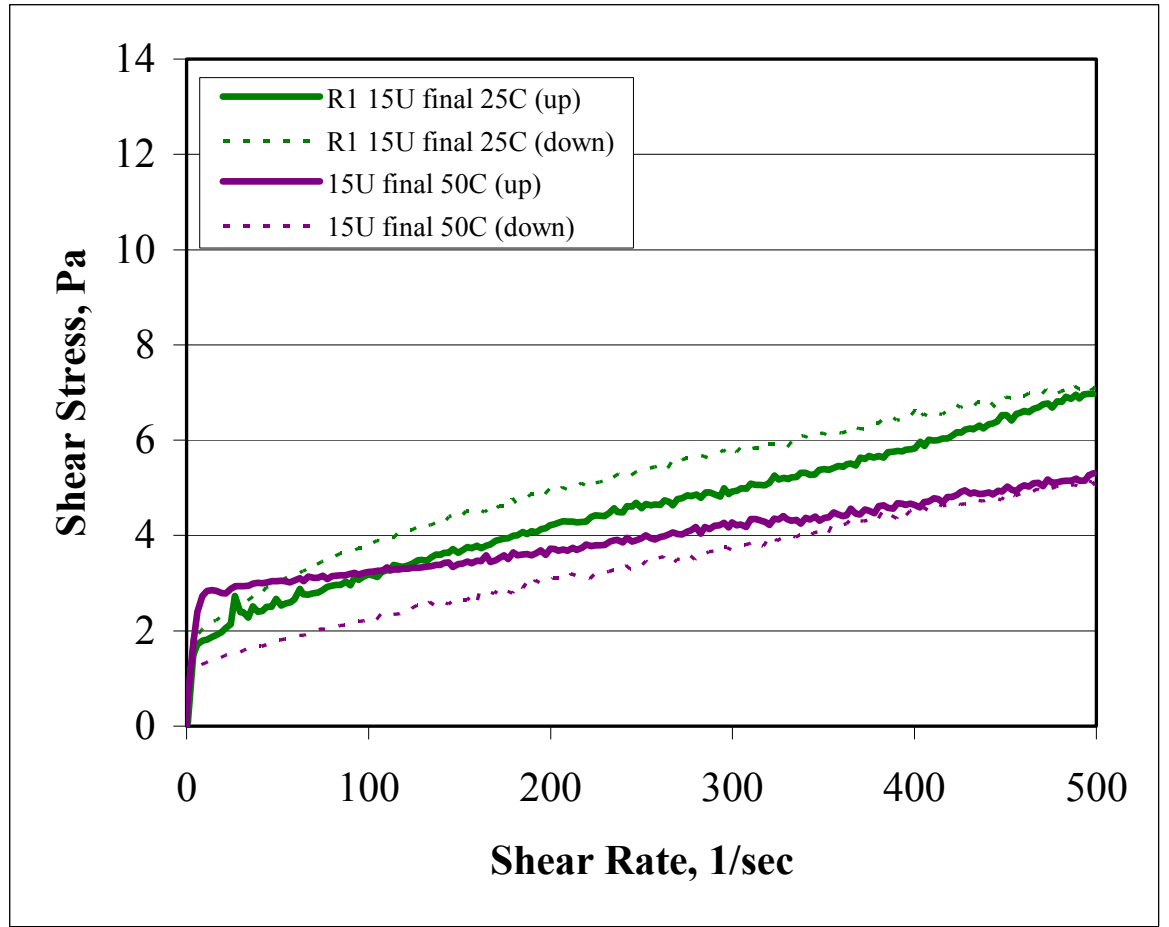

Figure 11. Rheogram of $15 \%$ Uranium Solids at 50 C and Room Temperature (25 C) 


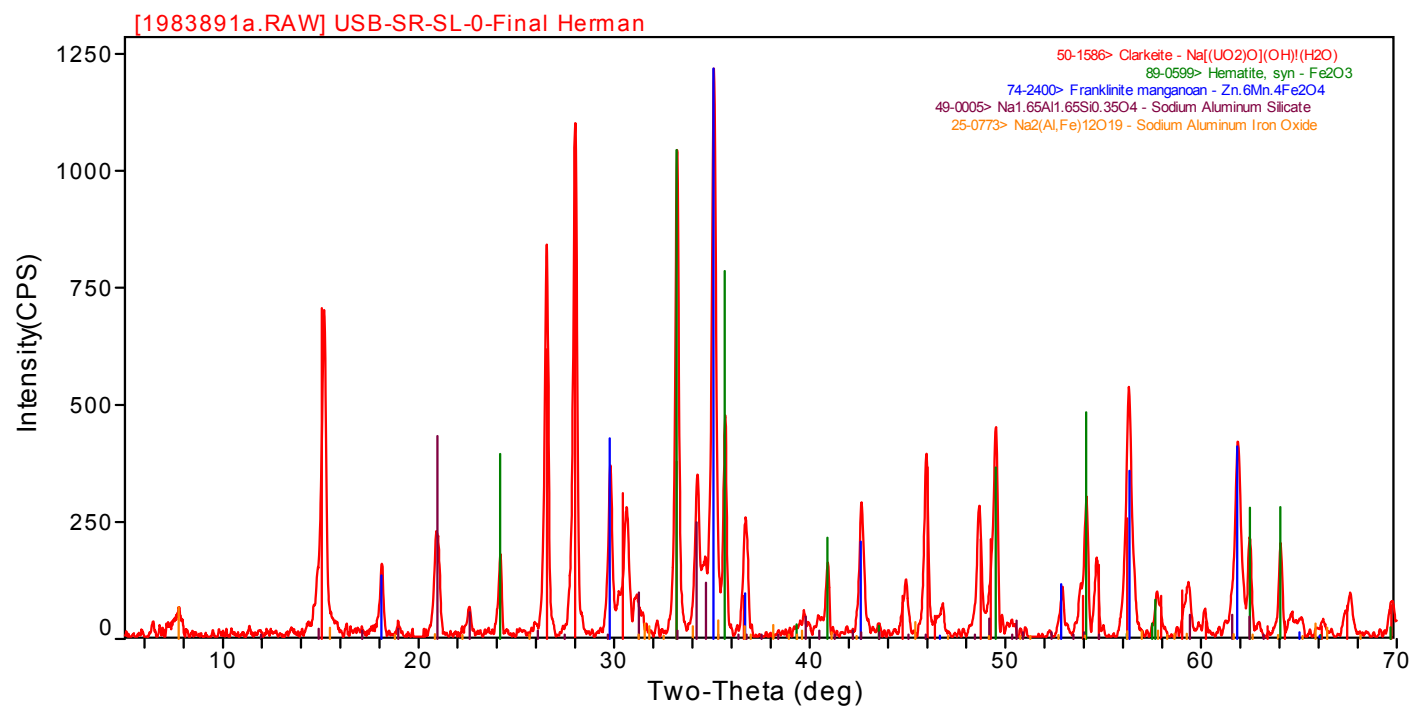

\subsection{X-ray Diffraction Results}

X-ray diffraction patterns were obtained on each of the SRAT products to determine the compounds in the slurries. The results are shown in Figure 12, Figure 13 and Figure 14.

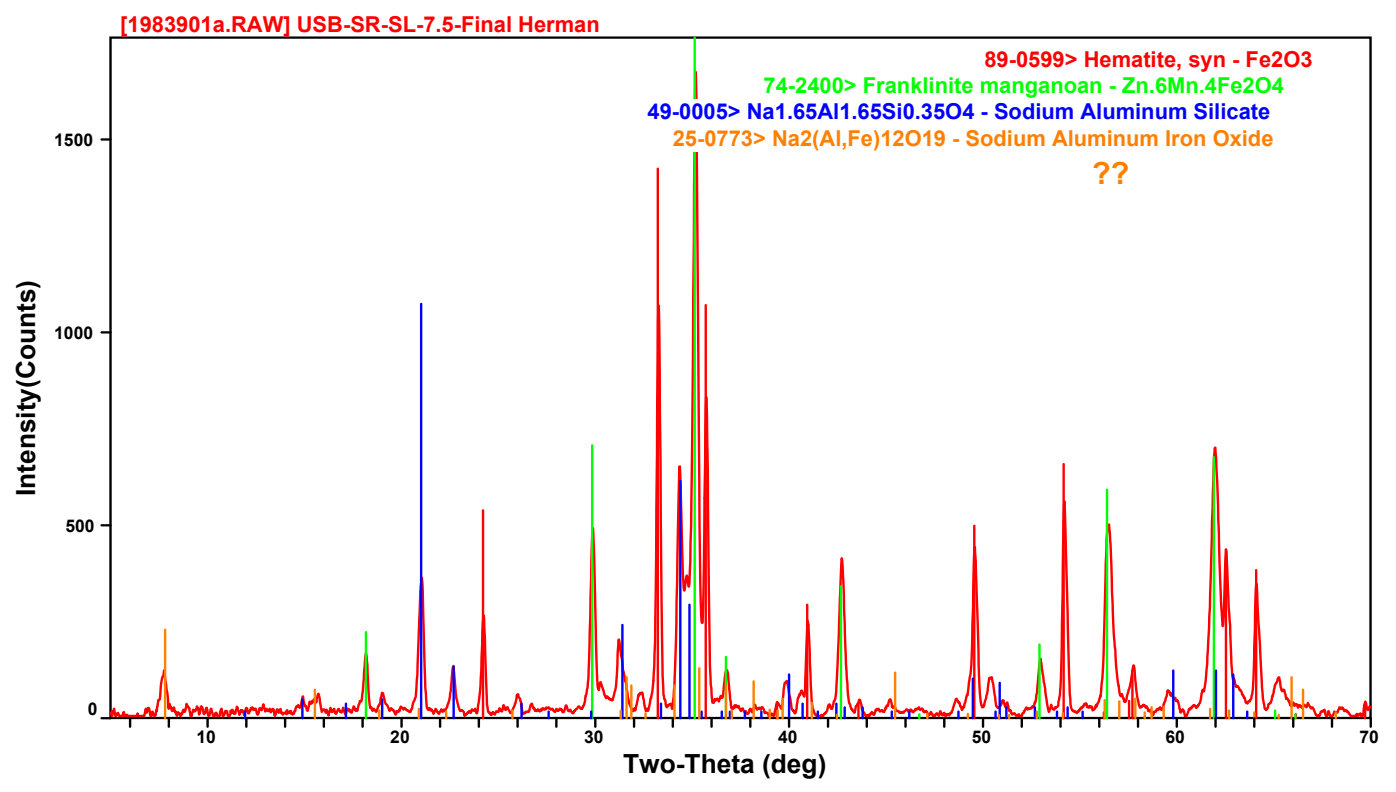

Figure 12. X-ray Spectra for Final Product with No Uranium Added

Figure 13. X-ray Spectra for Final Solution with $7.5 \mathrm{Wt} \%$ Uranium in the Solids of the Feed 
In the spectra for the $7.5 \mathrm{wt} \%$ uranium case, Clarkeite was found as the only phase of uranium. Additionally, sodium aluminum silicate and sodium aluminum iron oxides were found in this slurry.

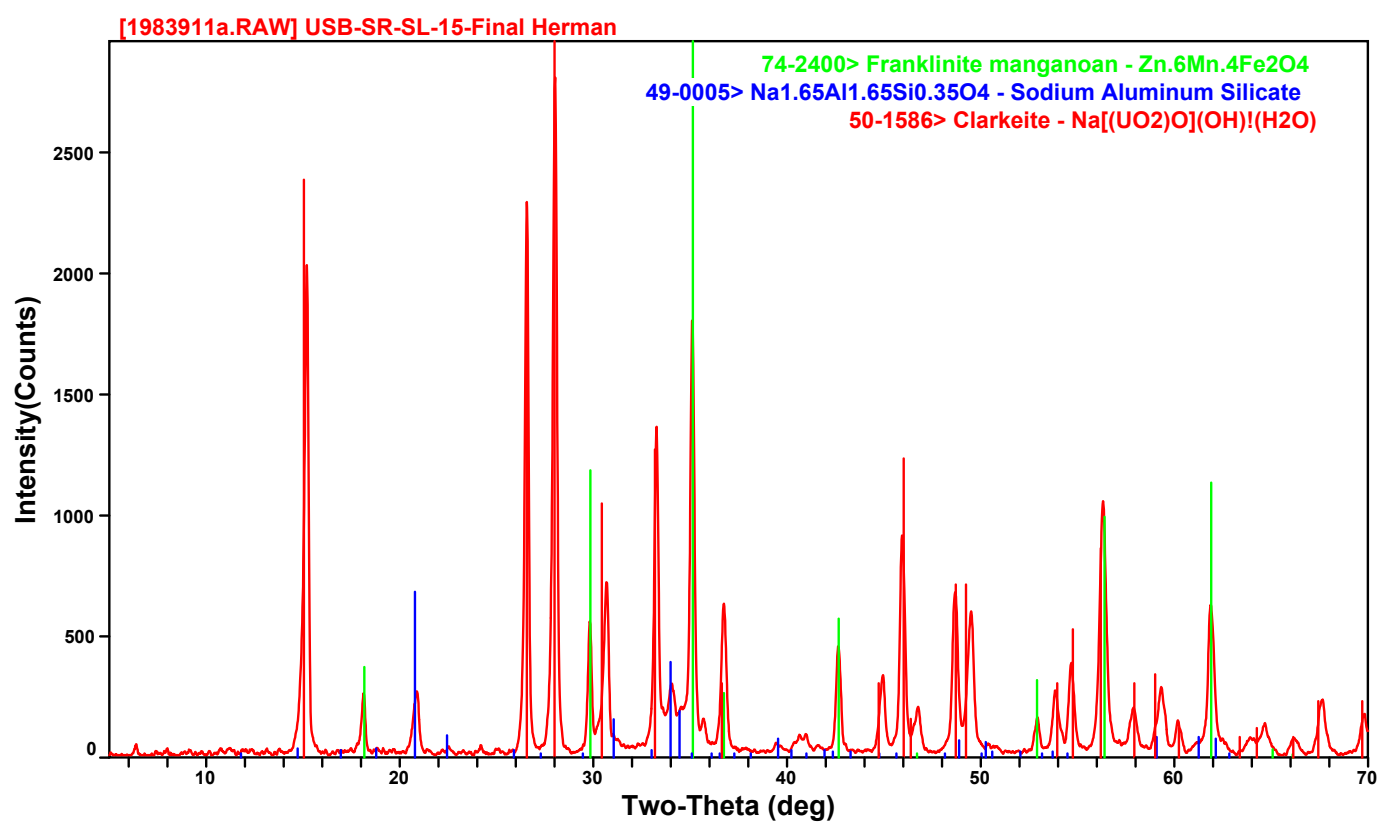

Figure 14. X-ray Spectra for Final Solution with $15 \mathrm{Wt} \%$ Uranium in the Solids of the Feed

As with the $7.5 \mathrm{wt} \%$ slurry, the only uranium phase found in the $15 \mathrm{wt} \%$ slurry was Clarkeite. Another compound of interest was sodium-aluminum-silicate. The analysis also showed that the hematite and the sodium aluminum iron oxide compounds were not found in the $15 \mathrm{wt} \%$ slurry.

\subsection{Settling}

A sample from each of the SRAT products was placed into $10 \mathrm{~mL}$ graduated cylinders and allowed to settle for several days. After approximately 4 days, the slurry with no uranium had a very small supernate layer, approximately $0.2 \mathrm{~mL}$ of the $10 \mathrm{~mL}$ of slurry. The $7.5 \mathrm{wt} \%$ slurry showed very little supernate at all but the volume in the graduated cylinder dropped to $9.4 \mathrm{~mL}$ from the initial $10 \mathrm{~mL}$. The $15 \mathrm{wt} \%$ slurry showed much better settling characteristics as a supernate layer of approximately $0.8 \mathrm{~mL}$ formed. This layer initially formed several hours after the initiation of the test and steadily increased as the slurry settled. These crude tests show that there might be a difference in the settling behavior of the sludge depending upon the uranium level. They would also support the rheology results.

\subsection{Conclusions}

Titration of uranyl nitrate solutions showed a greater acid demand as uranium levels were increased. The acid demand was also greatly affected by the rate at which the acid was added to the solution. Titrations using sludge simulant with added uranium showed similar results, though the effect of doubling the uranium concentration was not as dramatic as the inclusion of the first level of uranium in the simulant. Acid demand for the simulant was shown to be greatly dependent upon the acid addition rate, as was found in the titrations of uranium solutions. The rate of acid addition has been shown to change the equivalence demand by as much as 100 percent. 
Under similar conditions where the acid addition rate was held constant and the only difference in the feed was the amount of uranium added, the titrations performed showed that acid demand increased with an increase in uranium concentration.

Changes in slurry properties were also seen with different uranium concentrations. The baseline level of uranium (i.e. similar to the uranium concentration in the actual Sludge Batch 2 feed) demonstrated the highest viscosity.

\subsection{Recommendations}

The results of this study have not conclusively shown that the elevated levels of uranium in Sludge Batch 2 are the cause of Chemical Processing Cell processing problems. However, several changes in sludge properties during testing have indicated that the uranium is having some effect on the physical behavior of the sludge. It is believed that further testing is warranted based on the results of this study. Several factors should be considered in any future testing as discussed below.

It was determined that simply adding uranium to the existing simulants did not provide an acceptable replication of actual sludge. Therefore, it is recommended that any future work should incorporate the uranium in the feed preparation. This should provide a more representative simulant for testing.

Further testing should include additional levels of uranium concentration. If a specific range of uranium concentrations are having a detrimental effect on slurry properties then an attempt should be made to identify the range. It should be determined if the initial slurry properties observed, specifically the more viscous $7.5 \mathrm{wt} \%$ slurry can be duplicated. Testing should include the determination of phases at $\mathrm{pH}$ levels that are typical during SRAT processing to determine if there are specific phase compositions impacting processing.

Additional rheology samples should be taken at different $\mathrm{pH}$ levels specifically in the range of DWPF processing to determine if the actual slurry properties can be reproduced on a laboratory scale.

\subsection{References}

1. P. M. Patel, Technical Task Request, "Investigation of Sludge Batch 2 Processing Issues in DWPF (U)", HLW/DWPF/TTR-02-0035, January 14, 2003.

2. D. T. Herman and W. R. Wilmarth, " Determination of the Effect of Uranium Levels on Sludge Batch 2 Processing," WSRC-RP-2003-00314, March 13, 2003.

3. R. A. Pierce, "Chemical and Physical Behavior of Slurries During Neutralization of Simulated 2H Evaporator Waste Solutions," WSRC-TR-2000-00463, November 17, 2000.

4. T. L. Fellinger, J. M. Pareizs, N. E. Bibler, A. D. Cozzi, and C. L. Crawford, "Confirmation Run of the DWPF SRAT Cycle Using the Sludge-Only Flowsheet with Tank 40 Radioactive Sludge and Frit 200 in the Shielded Cells Facility (U)", WSRC-TR-2002-00076, April 30, 2002.

\subsection{Acknowledgements}

The authors would like to thank Mary Moss, David Healy, Cathy Coffey, Carl Black, Jon Duvall, Sammie King for performing the titrations, preparing solutions and slurries, and performing the SRAT cycles. We would also like to thank David Koopman, Erich Hansen and Debbie Marsh for rheology work, David Best and Pat Toole for analytical Support and the Analytical Development Section for initial sludge sample analysis and XRD on SRAT products. Additionally, we would like to extend our appreciation to Stacie Usry for support in bringing this report together. 
WSRC-TR-2003-00402

Revision 0

\section{Distribution:}

